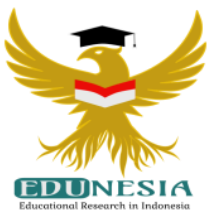

\title{
Studi Tentang Prestasi Anak Rawa yang Mengandalkan Bakat dan Minat Terhadap Keterbatasan Sarana Prasarana di SMAN 1 Danau Panggang
}

\author{
Noraini \\ Pendidikan Biologi, SMAN 1 Danau Panggang Kab.HSU,Kalsel, Indonesia \\ Corresponding Email: norainihsu3@gmail.com, Phone Number:0812 xxxx xxxx
}

Article History:

Received: Nov 06, 2020

Revised: Nov 10, 2020

Accepted: Nov 11, 2020

Published: Jan 01, 2021

\section{Keywords:}

Achievement, Swamp

Children, Talent and

Interests

Kata Kunci:

Anak Rawa, Bakat dan

Minat, Prestasi,

\section{How to cite:}

Noraini, N. (2021). Studi

Tentang Prestasi Anak Rawa yang Mengandalkan Bakat dan Minat Terhadap Keterbatasan Sarana Prasarana di SMAN 1 Danau Panggang. Edunesia: Jurnal Ilmiah Pendidikan, 2 (1): 85-92.

This is an open access article under the CC-BY-NC-ND license

\begin{abstract}
The purpose of writing a paper is to explain how swamp children can achieve achievement in limited infrastructure through their talents and interests, explain the definition of achievement, understanding of talents, factors that influence talent, interests, factors that influence interest. The sampling technique was carried out directly with the instrument to students who won 1,2 and 3 championships through interviews and literature studies. The results of the study and data obtained from the vice principal for student affairs concluded that the achievements of swamp children at SMAN 1 Danau Panggang were obtained because of a strong interest and supported by the talents possessed by each individual to participate in competitions or competitions. Achievement is the result of an activity that has been done, created, either individually or in groups. Talent is a number of characters, conditions or qualities that a person has from birth (innate) in the form of potential (potential ability) that will affect a person's chances of success in a certain field of work. Interest is a source of motivation that encourages people to do what they want if they are free to choose. Besides, support from teachers and parents is also a big part of achieving the achievements they expect.
\end{abstract}

Abstrak: Tujuan penulisan makalah adalah untuk menjelaskan bagaimana anak rawa dapat meraih prestasi dalam keterbatasan sarana prasarana melalui bakat dan minat yang dimiliki mereka, menjelaskan pengertian prestasi, pengertian bakat, faktor-faktor yang mempengaruhi bakat, minat, faktor-faktor yang mempengaruhi minat. Teknik pengambilan sampel dilakukan secara langsung dengan instrumen terhadap siswasiswa yang meraih prestasi juara 1,2 dan 3 melalui interview dan Studi literatur. Hasil studi dan data-data yang diperoleh dari wakil kepala sekolah bidang kesiswaan menyimpulkan bahwa prestasi-prestasi Anak Rawa pada SMAN 1 Danau Panggang diperoleh karena adanya minat yang kuat dan didukung oleh adanya bakat yang dimiliki setiap individu untuk mengikuti perlombaan atau pertandingan. Prestasi adalah hasil dari suatu kegiatan yang telah dikerjakan, diciptakan, baik secara individual maupun kelompok. Bakat adalah sejumlah karakter, kondisi atau kualitas yang dimiliki seseorang sejak lahir (bawaan) yang berupa potensi (potential ability) yang akan berpengaruh terhadap kemungkinan keberhasilan seseorang dalam suatu bidang pekerjaan. Minat merupakan sumber motivasi yang mendorong orang untuk melakukan apa yang mereka inginkan bila mereka bebas memilih.. Disamping itu, dukungan dari guru dan orang tua juga merupakan andil besar dalam meraih prestasi yang mereka harapkan. 


\section{A. Pendahuluan}

SMAN 1 Danau Panggang dibangun di atas rawa yang terletak di Kecamatan Danau Panggang. Kecamatan ini termasuk dalam lingkup Kabupaten Hulu Sungai Utara. Sebagian besar area di sekitar bangunan sekolah adalah genangan air yang disebut rawa. Untuk mengakrabkan dengan rawa maka muridnya penulis istilahkan Anak Rawa karena Sekolah dan Rumah murid umumnya dibangun di atas Rawa yang tergenang air hampir sepanjang tahun.

Rawa merupakan genangan air di daratan sebagai akibat letaknya yang lebih rendah dari daerah sekitarnya. Hal ini menyebabkan airnya tidak dapat mengalir keluar dan akan terakumulasi di tempat tersebut dan tanah di dasar rawa akan jenuh air. Menurut Kodoatie dan Sjarief (2012) rawa yaitu sumber daya air berupa genangan air terus menerus atau musiman yang terbentuk secara alamiah dan merupakan satu kesatuan jaringan sumber air dan mempunyai ciri-ciri khusus secara fisik, kimiawi dan biologis.

Rawa dapat dijadikan habitat oleh berbagai organisme atau makhluk hidup, seperti manusia, tumbuhan dan hewan air. Habitat adalah tempat tinggal suatu jenis makhluk hidup dalam sebuah kompleks kehidupan (ekosistem). Menurut Morisson (2011) dimana pun suatu organisme diberi sumber daya yang berdampak pada kemampuan untuk bertahan hidup, di situlah yang disebut dengan habitat.

Rawa bagi hewan dan tumbuhan air merupakan tempat tinggal yang cocok sehingga mereka dapat bertahan hidup dan berkembangbiak dengan baik. Tetapi rawa bagi manusia merupakan tempat tinggal yang terbatas untuk melakukan berbagai aktivitas dibandingkan dengan daerah lain yang bukan rawa. Kondisi ini semakin parah lagi jika tidak dilengkapi dengan fasilitas yang memadai, seperti yang di alami oleh anakanak rawa yang bersekolah di SMAN 1 Danau Panggang.

Keterbatasan fasilitas sarana dan prasarana dan kondisi fisik geografis rawa seringkali menjadi kendala atau masalah bagi anak-anak rawa dalam meraih prestasi setara dengan anak-anak lain yang bersekolah di kecamatan lain atau di dareah perkotaan. Namun anak rawa punya semangat yang hanya ditunjang bakat, minat dan cita-cita tinggi untuk dapat meraih prestasi. Semangat dan cita-cita mereka sangat didukung oleh guru dan orang tua mereka. Sehingga mereka mampu meraih beberapa prestasi yang membanggakan dari tingkat kecamatan,kabupaten sampai ke Provinsi.

\section{B. Metode}

Metode penulisan makalah ini adalah interview dan Studi literatur Dalam penyusunan makalah ini penulis menggunakan referensi dari buku-buku, memilih beberapa situs internet sebagai sumber rujukan dan pengumpulan data melalui interview kepada siswa-siswa yang meraih prestasi sebagai juara 1, 2 dan 3 serta beberapa narasumber yang terkait dengan masalah ini. 
C. Hasil Penelitian.

Tabel 1.

Ringkasan Daftar Prestasi yang pernah diraih oleh Anak Rawa SMAN 1 Danau Panggang.

\begin{tabular}{|c|c|c|c|c|}
\hline No & Tahun & $\begin{array}{c}\text { Bidang } \\
\text { Kegiatan }\end{array}$ & Prestasi & Tingkat \\
\hline \multirow{6}{*}{1} & \multirow{6}{*}{2014} & \multirow{3}{*}{$\begin{array}{l}\text { Olympiade } \\
\text { Sains }\end{array}$} & a. Aris Pratama Juara 1 TIK & \multirow{3}{*}{ Kabupaten } \\
\hline & & & b. Bahriannor Juara 3 Kebumian & \\
\hline & & & c. Suryadi Juara 3 TIK & \\
\hline & & \multirow[t]{2}{*}{ Seni } & $\begin{array}{l}\text { a. Riska Safitri Juara } 1 \text { Lomba } \\
\text { bercerita }\end{array}$ & \multirow{3}{*}{ Kabupaten } \\
\hline & & & b. Khairi Juara 1 Tenis Meja & \\
\hline & & $\begin{array}{l}\text { Olympiade } \\
\text { Olah Raga }\end{array}$ & $\begin{array}{l}\text { c. Ratu Juara } 3 \text { Karate Komite } 53 \\
\mathrm{Kg}\end{array}$ & \\
\hline 2 & 2014 & $\begin{array}{l}\text { Olympiade } \\
\text { Sains }\end{array}$ & a. Aris Pratama Juara 2 TIK & Provinsi \\
\hline \multirow{5}{*}{3} & \multirow{5}{*}{2015} & \multirow{2}{*}{ Olimpiade Sains } & a. Fahriannor Juara 1 Kebumian. & \multirow{2}{*}{ Kabupaten } \\
\hline & & & b. Nor Asyiah Juara 2 Komputer. & \\
\hline & & \multirow{3}{*}{$\begin{array}{l}\text { Olympiade } \\
\text { Olah Raga }\end{array}$} & $\begin{array}{l}\text { a. Windi Ariadi Juara } 1 \text { Tenis } \\
\text { Meja }\end{array}$ & \multirow{3}{*}{ Kabupaten } \\
\hline & & & b. Hamdiah Juara 2 Catur Putri & \\
\hline & & & $\begin{array}{ll}\text { c. } & \text { Suci Kurniawan Juara } 1 \\
\text { lompat jauh putra }\end{array}$ & \\
\hline \multirow{7}{*}{4} & \multirow{7}{*}{2016} & \multirow{5}{*}{$\begin{array}{l}\text { Olympiade } \\
\text { Olah Raga }\end{array}$} & a. Siah Juara 2 Lompat jauh & \multirow{5}{*}{ Kabupaten } \\
\hline & & & $\begin{array}{l}\text { b. Riduan juara } 2 \text { Lompat Jauh } \\
\text { Putra }\end{array}$ & \\
\hline & & & $\begin{array}{l}\text { c. Siti Aisyah Juara } 1 \text { Lompat } \\
\text { jauh }\end{array}$ & \\
\hline & & & $\begin{array}{l}\text { d. Qomariah Juara } 1 \text { Karate Putri } \\
\text { kls } 53 \mathrm{Kg}\end{array}$ & \\
\hline & & & $\begin{array}{l}\text { e. Jamiatul Hasanah Juara } 2 \\
\text { Karate Putri kls } 53 \mathrm{Kg}\end{array}$ & \\
\hline & & \multirow{2}{*}{$\begin{array}{l}\text { Olympiade } \\
\text { Olah Raga }\end{array}$} & $\begin{array}{l}\text { a. Suci Kurniawan Juara } 1 \\
\text { lompat jauh putra }\end{array}$ & \multirow{2}{*}{ Provinsi } \\
\hline & & & $\begin{array}{l}\text { b. M.andri Juara } 2 \text { Lompat Jauh } \\
\text { Putra }\end{array}$ & \\
\hline 5 & 2017 & $\begin{array}{l}\text { Olympiade } \\
\text { Olah Raga }\end{array}$ & a. Riska Ainiyah Juara 1 Karate & Kabupaten \\
\hline
\end{tabular}




\begin{tabular}{|c|c|c|c|c|}
\hline No & Tahun & $\begin{array}{c}\text { Bidang } \\
\text { Kegiatan }\end{array}$ & Prestasi & Tingkat \\
\hline & & & Putri. & \\
\hline & & Olympiade Seni & b. Faisal Fahmi Juara 1Gitar Solo & Kabupaten \\
\hline \multirow{2}{*}{6} & \multirow{2}{*}{2018} & \multirow{2}{*}{$\begin{array}{l}\text { Olympiade } \\
\text { Olah Raga }\end{array}$} & $\begin{array}{l}\text { a. Akhmad Nazi Juara } 1 \text { renang } \\
\text { putra }\end{array}$ & \multirow{2}{*}{ Kabupaten } \\
\hline & & & $\begin{array}{l}\text { b. Ahmad Nazar Pratama Juara } 2 \\
\text { Jauh }\end{array}$ & \\
\hline \multirow[t]{2}{*}{7} & \multirow[t]{2}{*}{2019} & $\begin{array}{l}\text { Olimpiade } \\
\text { Statistik }\end{array}$ & a. Nor Asiah Juara 1 Statistik & Kabupaten \\
\hline & & $\begin{array}{l}\text { Olympiade } \\
\text { Olah Raga }\end{array}$ & b. Nor Syifa Juara 2 Renang & Provinsi \\
\hline \multirow{4}{*}{8} & \multirow{4}{*}{2020} & $\begin{array}{l}\text { Olympiade } \\
\text { Sains }\end{array}$ & a. Norkamaliah Juara 1 Fisika & Kabupaten \\
\hline & & $\begin{array}{l}\text { Olympiade } \\
\text { Sains }\end{array}$ & b. Siti Hasanah Juara 1 Komputer & Kabupaten \\
\hline & & $\begin{array}{l}\text { Olympiade } \\
\text { Sains }\end{array}$ & c. A.Fadillah Juara 1 Biologi & Kabupaten \\
\hline & & Olympiade Seni & d. Siti Asiah Juara 1 Tilawah & Provinsi \\
\hline
\end{tabular}

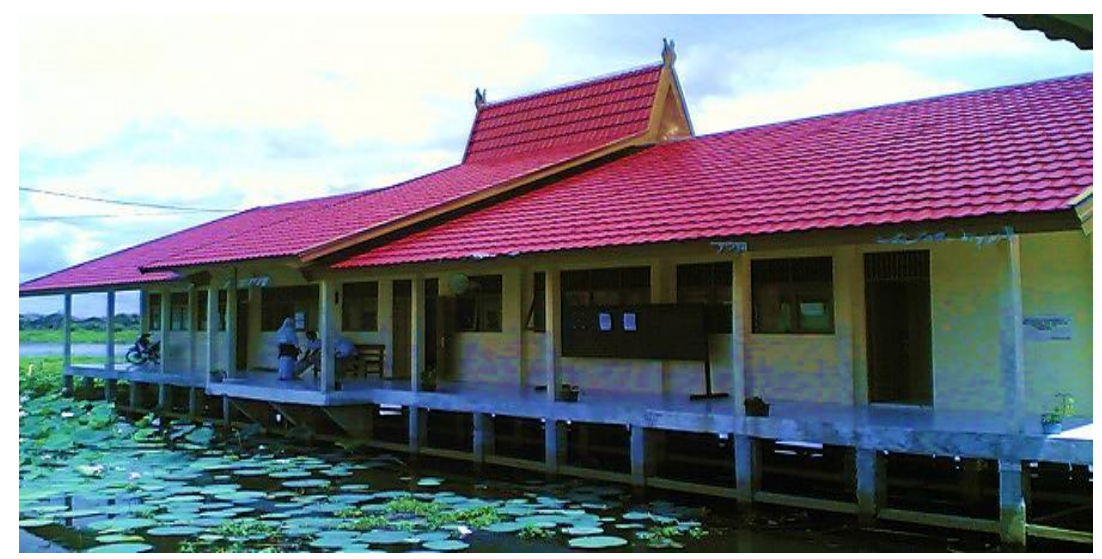

Gambar 1. Kondisi SMAN 1 Danau Panggang yang dibangun di atas genangan air rawa.

Berdasarkan tabel 1 Ringkasan Daftar Prestasi yang pernah diraih oleh Anak Rawa SMAN 1 Danau Panggang, dari tahun 2014 sampai 2020, terlihat cukup banyak prestasi yang dapat diraih oleh anak-anak rawa SMAN 1 Danau Panggang. Prestasi yang mereka dapatkan mencakup beberapa bidang yaitu Olympiade Olahraga, Olympiade sains, Olympiade bahasa dan seni.

Jika kita pilah prestasi yang cukup membanggakan bagi anak-anak rawa SMAN 1 Danau Panggang adalah dalam bidang Olahraga dan Olympiade Sains. Prestasi-prestasi yang mereka dapatkan mengandalkan minat dan bakat yang mereka miliki dengan hanya sedikit atau bahkan tidak pernah melakukan latihan sebelum ikut lomba. 
Berdasarkan hasil wawancara waktu dahulu dan sekarang ini kepada para responden dan pengamatan langsung ke lapangan sebagian besar dari mereka dalam memperoleh prestasi hanya mengandalkan minat dan bakat ditambah sedikit atau bahkan tidak pernah melakukan latihan sedikitpun sebelum mengikuti lomba.

Seperti dikatakan Aris Pratama Juara I Olympiade sains bidang Komputer, hanya sekitar 6 kali les materi dan sedikit latihan soal. Dia juga hanya mengandalkan minat yang kuat yang didukung dengan kecerdasan alami (bakat) yang dimilikinya. Guru yang membimbingnya pun bukan guru TIK tetapi dianggap mampu untuk membimbing les persiapan Olympiade sains Komputer.

Hal serupa dikatakan Arif Rahman Juara I atlet lari 100 meter, tidak ada persiapan yang serius dalam menghadapi lomba lari tersebut. Dia hanya mengandalkan minat yang kuat dengan bakat yang dimilikinya. Hal ini dilakukan karena keterbatasan fasilitas yang menunjang untuk atlet lari 100 meter. Disamping itu yang menguatkan tekatnya untuk dapat meraih juara I adalah adanya motivasi dan dukungan dari guru dan orang tua.

Contoh lainya adalah seperti yang dialami Faisal Fahmi Juara I lomba gitar Solo dan Riska Ainiyah juara 1 Karate Putri. Mereaka sebelum tampil mewakili SMAN 1 Danau Panggang, tidak banyak hari yang digunakan Faisal dan Riska untuk latihan. Mereka hanya berlatih sekitar semingu sebelum tampil dalam lomba dan pertandingan tersebut. Faisal saat itu merupakan siswi kelas XII IPS-1 dan Riska Ainiyah yang sekarang ini duduk di kelas XII IPA-,merupakan siswa yang berbakat dan berminat pada bidangnya komite karate. Disamping itu dukungan guru dan orang tua yang menguatkan bakat dan minatnya. Terbukti orang tuanya hadir menyaksikan saat pertandingan komite karate.

Jadi dapat disimpulkan bahwa prestasi-prestasi anak rawa di SMAN 1 Danau Panggang diperoleh karena adanya minat yang kuat dan didukung oleh adanya bakat yang dimiliki setiap individu yang mengikuti perlombaan atau pertandingan. Disamping itu, dukungan dari guru dan orang tua juga merupakan andil besar yang mereka harapkan dalam meraih prestasi.

Menurut Anonim (2018), prestasi adalah hasil yg telah dicapai dari yg telah dilakukan, dikerjakan, dan sebagainya. Istilah prestasi berasal dari bahasa Belanda yaitu prestatie, kemudian dalam bahasa Indonesia menjadi prestasi yang berarti hasil usaha. Prestasi adalah penguasaan pengetahuan/keterampilan yang dikembangkan melalui mata pelajaran, ditunjukkan dengan nilai tes (KBBI, 2016). Menurut Hamdani (2011) prestasi yaitu hasil dari suatu kegiatan yang telah dikerjakan, diciptkan baik secara individual maupun kelompok. Sedangkan menurut Djamarah (2012) prestasi yaitu hasil dari suatu kegiatan yang telah dikerjakan, diciptakan, yang menyenangkan hati yang diperoleh dengan jalan keuletan kerja, baik secara individual maupun kelompok dalam bidang kegiatan tertentu.

Menurut Syah (2010), Prestasi adalah tingkat keberhasilan siswa dalam mencapai tujuan yang telah ditetapkan dalam sebuah program. Jika dihubungkan dengan pendidikan, maka Suryabrata (2013), mengemukakan bahwa "Prestasi belajar adalah nilai yang merupakan perumusan terakhir yang dapat diberikan oleh guru mengenai kemajuan/prestasi belajar selama masa tertentu.

Pendapat senada juga diungkapkan oleh James (2010) bahwa "Prestasi belajar merupakan hasil belajar yang telah dicapai atau hasil keahlian dalam karya akademis yang dinilai oleh guru, lewat tes-tes yang dilakukan atau lewat kombinasi kedua hal tersebut". Dalam hal ini misalnya prestasi belajar siswa selama satu semester yang diukur 
dengan nilai beberapa mata pelajaran yang harus ditempuh selama satu semester tersebut, jika siswa bisa mengumpulkan nilai yang tinggi dalam masing-masing mata pelajaran dan mengumpulkan jumlah yang tinggi atau lebih dari yang lain berarti siswa tersebut mempunyai prestasi belajar yang tinggi.

Hasil belajar atau prestasi yang tinggi dibidang psikomotorik (keterampilan) dalam perlombaan seni dan olahraga tentu saja di dapatkan dengan pengembangan bakat dan minat yang dimiliki oleh peserta didik, meskipun di SMAN 1 Danau Panggang masih memiliki keterbatasan sarana prasana yang menunjang pengembangan bakat dan minat tersebut.

Bakat adalah sejumlah karakter, kondisi atau kualitas yang dimiliki seseorang sejak lahir (bawaan) yang berupa potensi (potential ability) yang akan berpengaruh terhadap kemungkinan keberhasilan seseorang dalam suatu bidang pekerjaan. Bakat tersebut masih perlu dikembangkan atau dilatih. Meskipun potensi ini sudah ada di dalam seseorang, tetap dibutuhkan latihan dan pengembangan secara serius, sistematis dan terus-menerus agar dapat terwujud. Jika tidak dilatih atau dikembangkan bakat tidak akan mendatangkan manfaat apapun bagi orang yang memilikinya.

Menurut Risman (2012), seorang psikolog dari Yayasan Kita dan Buah Hati, wujud dari bakat adalah prestasi. Untuk mengembagkan bakat menjadi prestasi diperlukan latihan, pengetauhan, pengalaman dan motivasi.

Secara umum bakat dibedakan menjadi 2 yaitu:

1. Bakat Umum

Merupakan kemampuan berupa potensi yang bersifat umum. Bakat umum biasanya berkenaan dengan intelektual seseorang. Bakat umum biasanya diistilahkan dengan gifted.Contoh: seorang anak yang bakat umum disebut gifted child,memiliki itelegensi di atas rata-rata (ber IQ 120 atau lebih).

2. Bakat Khusus

Merupakan kemampuan bawaan yang berupa potensi dalam bidang tertentu. Individu yang memiliki bakat khusus apabila mendapat kesempatan untuk mengembangkan secara optimal dengan motivasi tinggi akan memiliki kemampuan khusus dan prestasi yang menonjol. Bakat khusus juga disebut talent.Contoh: seseorang yang memiliki bakat olah raga, tari, musik dan masih banyak lagi bakat-bakat yang lainnya. Conny Semiawan dan Utami Munandar (2010) menggolongkan bakat khusus a.l :

a. Bakat akademik khusus, yaitu bakat dalam bidang angka, logika bahasa, dan lainlain. Tokoh yang mempunyai bakat seperti itu misalnya J.K. Rowling, penulis seri Harry Potter. Ia di angggap berbakat dalam bidang logika bahasa karena bukunya yang luar biasa dan terjual jutaan kopi dalam berbagai bahasa.

b. Bakat kreatif produktif, yaitu bakat untuk menciptakan suatu penemuan baru. Tokoh yang berbakat seperti ini misalnya Thomas Alva Edison, pencipta berbagai penemuan seperti bola lampu.

c. Bakat karakteristik atau psikomotorik, misalnya bakat dalam bulu tangkis, sepak bola dan lain-lain. Tokoh yang terkenal misalnya Diego Maradona yang dijuluki 'Si Kaki Emas' karena tendangannya dalam sepak bola.

Faktor yang mempengaruhi bakat secara umum dibedakan sebagai berikut :

1. Faktor yang Mempengaruhi Bakat Umum

Seperti yang telah dijelaskan sebelumnya, bahwa bakat umum biasanya merupakan kemampuan intelegensi seseorang. Menurut Plomin (2010) 
berpendapat bahwa intelegensi ditentukan oleh $50 \%$ genetik dan $50 \%$ lingkungan. Hal ini berarti bahwa keadaan lingkungan dapat mempengaruhi tingkat intelegensi seseorang yang menentukan peningkatan prestasi sekolah dan perolehan ketrampilan yang diperlukan untuk bekerja.

\section{Faktor yang Mempengaruhi Bakat Khusus}

Bakat khusus dipengaruhi oleh sejumlah faktor yang dikelompokkan menjadi faktor internal (faktor yang berasal dari individu) dan faktor eksternal (faktor yang barasal dari lingkungan tempat individu tumbuh dan berkembang).

Disamping bakat, kita juga jangan melupakan kemauan siswa yang tidak ingin dipaksa dalam memilih suatu perlombaan atau pertandingan yang dikehendakinya dalam semua bidang atau kita harus memperhatikan siswa dalam hal minatnya.

Minat diartikan sebagai kehendak, keinginan atau kesukaan (Kamisa, 2012). Minat adalah sesuatu yang pribadi dan berhubungan erat dengan sikap. Minat merupakan sumber motivasi yang mendorong orang untuk melakukan apa yang mereka inginkan bila mereka bebas memilih. Minat juga merupakan salah satu faktor yang dapat mengarahkan bakat, dan keberadaannya merupakan faktor utama dalam pengembangan bakat.

Menurut Anonim (2018), minat yang muncul dalam pikologis siswa merupakan sebuah gejala, sehingga munculnya minat tersebut dipengaruhi oleh beberapa faktor yang menjadi penyebabnya. Faktor tersebut diantaraya; faktor individu dan sosial.

Dalam sumber lain, Chauhan (2012) menyebutkan bahwa faktor yang mempengaruhi minat diantaranya: Perkembangan Fisik dan Perbedaan Jenis Kelamin.

\section{Kesimpulan.}

Prestasi-prestasi Anak Rawa di SMAN 1 Danau Panggang diperoleh karena adanya minat yang kuat dan didukung oleh adanya bakat yang dimiliki setiap individu yang mengikuti perlombaan atau pertandingan. Disamping itu, dukungan dari guru dan orang tua juga merupakan andil besar dalam meraih prestasi yang mereka harapkan. Prestasi adalah hasil dari suatu kegiatan yang telah dikerjakan, diciptakan, baik secara individual maupun kelompok.

Bakat adalah sejumlah karakter, kondisi atau kualitas yang dimiliki seseorang sejak lahir (bawaan) yang berupa potensi (potential ability) yang akan berpengaruh terhadap kemungkinan keberhasilan seseorang dalam suatu bidang pekerjaan.

Faktor yang mempengaruhi bakat umum biasanya karena intelegensi seseorang, sedangkan yang mempengaruhi bakat khusus karena faktor internal individu dan lingkungan.

Minat merupakan sumber motivasi yang mendorong orang untuk melakukan apa yang mereka inginkan bila mereka bebas memilih. Faktor yang mempengaruhi minat adalah fakor individu itu sendiri, sosial, perkembangan fisik dan perbedaan jenis kelamin.

\section{Daftar Pustaka}

Anonim. (2018). Faktor-faktor yang Mempengaruhi Minat Siswa Belajar Diakses dari http://id.shvoong.com/social-sciences/education/2134772-faktor-yangmempengaruhi-minat-siswa/ pada tanggal 26 Mei 2018. 
Anonim. (2018). Definisi Prestasi. Diakses dari www.artikata.com pada tanggal 22 Mei 2018.

Chauhan, S.S. (2012). Advanced Educational Psychology. New Delhi: Vikas Publishing Hous.

Djamarah, B.S. (2012). Prestasi Belajar Dan Kompetensi Guru. Surabaya: Usaha Nasional.

Hamdani. (2011). Strategi Belajar Mengajar. Bandung: Pustaka Setia.

James, C.P. (2011). Kamus Lengkap Psikologi. Terjemahan. Percetakan Rajawali Jakarta.

Kamisa. (2012). Kamus Lengkap Bahasa Indonesia. Surabaya: Kartika, PT PustakaUtama Grafindo.

Kamus Besar Bahasa Indonesia. (2016). Edisi Daring. Badan Pengembangan dan Pembinaan Bahasa, Kementerian Pendidikan dan Kebudayaan Republik Indonesia.

Kodoatie, R.J dan Sjarief, R. (2012). Pengelolaan Sumber Daya Air Terpadu. Andi Yogyakarta.

Morisson. (2011). Modeling Habitat Relationships of Terrestrial Vertebrate. Univ.Winconsin Press. Madison.

Munandar, S.C. (2010). Memupuk Bakat dan Kreativitas siswa sekolah menengah. Jakarta: PT Gramedia.

Plomin, R., \& Kosslyn, S.M. (2010). Genes, Brain and Cognition. Neurosci.

Risman, E. (2012). Biarkan Akan Bicara. Republika: Jakarta.

Syah, M. (2010). Psikologi Pendidikan dengan Pendekatan Baru. Bandung: PT Remaja Rosdakarya.

Suryabrata, S. (2013). Psikologi Pendidikan (Suatu Penyajian Secara Operasional). Yogyakarta: Rake Press. 